\title{
Outline of Structural Evolution of the Thaumasian Back-Arc Trap Province of Mars, and Related Rim -Orogenic Arcs: A Speculative Hypothesis Based on Earth Geology \\ Forese Carlo Wezel and Davide Baioni* \\ Planetary Geology Research Group, University of Urbino, Campus Scientifico Sogesta, 61029 Urbino, Italy
}

\begin{abstract}
The Thaumasian lava plateau developed within an already deformed domain, consisting of composite orogenic belts. A crude scheme of the deformation history of the Thaumasian plateau summarizing the most significant events of its polycyclic development is presented here. It is suggested that the region evolved in four tectonism phases: (1) alpinotype regional compression, formation of basement nappes (early and middle Noachian orogen); (2) late Noachian regional, domal uplift, and denudation of the internal fold belt; (3) late Noachian-early Hesperian supracrustal deformation, as décollement nappes; and (4) Hesperian crustal foundering and great effusion of trap basalts flooding of the inner, alreadypeneplain mountain belts, balanced by uplifting of peripheral arcuate rim-highlands (swells and mountain belts). The two orogenic arcs of the Coprates and Thaumasia -Claritas belts exhibit thrusting vergence and orogenic migration, $\mathrm{E}$ - and SW-directed, indicating the presence of topographic doming associated with plume activity, which was probably positioned, in the late Noachian, upon the modern Solis planum lowland. There is a substantial possibility that the two arcs followed different tectonic evolutions. The lateral intrusion of hot, mafic fluids in interconnected fractures, near the crust-mantle boundary, is supposed to have been an important driving mechanism of tectonism beneath the plateau region. The thick bodies of diapir-like, moving aqueous fluid were probably related to ascending deepmantle plumes.
\end{abstract}

\section{Introduction}

The vast Thaumasian plateau on Mars ( $2900 \mathrm{~km}$ in diameter) forms the south-eastern sector of the Tharsis magmatic complex, which represents a giant, elevated topographic bulge ( 10 km high), with characteristics that are similar to the expression of Earth's superplumes [1]. The Thaumasian region consists of high lava plains partially surrounded by ancient orogenic highlands. The volcanotectonic plateau region has had a long and complicated geological history, which has been the topic of several studies and the subject of various formation explanations, which can separated into two major groups: (a) mono history hypotheses (i.e., gravity translation of the plateau as a block or a slide), and (b) polyhistory hypotheses (i.e., orogenic lateral deformation).

The main purpose of this paper is to attempt to summarize briefly the sequence of tectonic movements (i.e., the kinematics) that created the present Thaumasian plateau configuration. The tentative kinematic scheme presented here may be important to elucidating not only Thaumasian structural evolution, but also early Mars, as well as the tectonic movements at the basin peripheries responsible for the episodic occurrence of widespread evaporite deposition, and the development of the huge canyon system of Valles Marineris [2] .

Complementary to the pertinent data that have been reported, the interpretation offered here attempts to outline a new scheme of succession of structural events. From this scheme, emerges the conception of a genetic association of the Thaumasian plateau with ancient orogenic zones beneath the plateau ("epi-orogenic plateau"). Moreover, we assume that the units tectonised in earlier phases have been reactivated at successive periods in more recent times (polycyclic tectonic deformation).

\section{Previous Hypotheses of Origin}

Here we present a brief review of various hypotheses that have been proposed to account for the genesis and geodynamic evolution of the Thaumasian lava plateau and its peripheral, outward-verging mountain belts. The genesis of these highlands is still controversial. Previous work focused attention mainly on recent plateau kinematics, without investigating complete deformation development.Recent contributions proposed the following hypotheses:

1. Crustal-scale, compressional buckling associated with thrust faulting on the Thaumasia plateau margins [3].

2. Deep crustal mafic dyke intrusion may have caused the uplift of the plateau during the Noachian and early Hesperian, producing the genesis of grabens in the middle of the dome and formation of outward-verging fold-and-thrust plateau margins [4].

3. Down sloping, south-eastward lateral movement of the Thaumasia plateau as a single, coherent lithospheric block that was affected by frontal thrusting and buckling $[5,6]$ along a $2000-\mathrm{km}$-long basal weak décollement surface $(10$ to $15 \mathrm{~km}$ deep) on thick salt deposits [7]. The compressional belts are considered to lie at the landslide toe of the crustal slab, and the salt deposits are early Noachian in age [7]. According to

"Corresponding Author: Prof. Davide Baioni, Dipartimento di Scienze Pure e Applicate, Università degli studi di Urbino "Carlo Bo", Campus Scientifico Enrico Mattei, 61029, Italy, Tel: +39 722 304298; E-mail: davide.baioni@uniurb.it

Citation: Wezel FC, Baioni D (2018) Outline of Structural Evolution of the Thaumasian Back-Arc Trap Province of Mars, and Related Rim -Orogenic Arcs: A Speculative Hypothesis Based on Earth Geology. Int J Earth Environ Sci 3: 153. doi: https://doi.org/10.15344/2456-351X/2018/153

Copyright: (c) 2018 Baioni et al. This is an open-access article distributed under the terms of the Creative Commons Attribution License, which permits unrestricted use, distribution, and reproduction in any medium, provided the original author and source are credited. 
Citation: Wezel FC, Baioni D (2018) Outline of Structural Evolution of the Thaumasian Back-Arc Trap Province of Mars, and Related Rim -Orogenic Arcs: A Speculative Hypothesis Based on Earth Geology. Int J Earth Environ Sci 3: 153. doi: https://doi.org/10.15344/2456-351X/2018/153

Page 2 of 8

a previous work [6], the Thaumasia plateau did not move as a single lithospheric block sliding from the Syria planum volcanic centre. Differential eastward movements of plateau blocks have been proposed, and three main deformational events have been recognized.

4. The plateau peripheral mountain belts have been interpreted to be the remnants of ancient orogenic belts, which formed during an ancient tectonic phase of powerful large-scale compressional deformation, as occurred in the alpinotype chains on Earth as a consequence of plate tectonics [5].

It is our view that the type of kinematics presented [5] better explain the complex tectonic events that have occurred than hypothesis 3 (above), which focuses attention almost exclusively on the closing plateau stage, probably due to post orogenic gravitational spreading [5] , without analysing the structures in their tectonic development. Thus, in the monogenetic hypothesis, the last tectonic episode is taken to represent the plateau's entire structural evolution, without consideration of the mountain chain below it. On the other hand, the polycyclic tectonic model can interpret repeated deformations and rearrangements that affected pre-existing structures.

Significant surface slopes are required on Earth to form thrusted and folded mountain belts by either gravity gliding or gravity spreading processes [8]. Thus, there is no known mechanism to explain the production of the Thaumasia lithospheric translation, given average regional slopes of $1^{\circ}$ or less [9]. Furthermore, the alleged 2000-kmlong basal detachment level is two orders of magnitude larger than any terrestrial counterparts [10].

We suggest that the plateau supracrustal features obscure the presence of infracrustal, deformed zones beneath the plateau. The formation of the plateau was the youngest episode of a set of repeated orogenic episodes affecting the Thaumasian region during the Noachian-Hesperian time span.

\section{The "basin and rim" Morphostructure}

The Thaumasia volcano tectonic region consists of a "lava plateau" that is covered by basaltic lavas and encircled by a partly annular frame of peripheral swells. At its eastern, southern, and western borders, the rim is formed by highland arcuate belts that constitute mountain ranges, with elevations of up to $5 \mathrm{~km}$ above Solis planum [11]. From the eastern to the western plateau margins, these outwardly verging arcuate mountain belts include Coprates rise, Thaumasia highlands, and Claritas rise. The bounding rim zones, which we prefer to call "mountain arcs", are characterized by evidence of intense geological deformation, thus representing "geo sutures" around a rigid block.

At the north-eastern margin, the plateau rim comprises the Valles Marineris, a vast and deep canyon system of parallel faulted troughs incising a broad plateau, which is considered to be either a manifestation of an extensional tectonism, comparable to terrestrial continental rifts [12], or an expression of a structural collapse [13] We presume that the Valles Marineris graben-like system originated on a rifted crest over a domal ridge, located within the Thaumasian rim, in the same way that the eastern branch (Gregory and Ethiopian rifts) of the East African rift-valley system formed, which has been interpreted to be located on top of Kenya and Ethiopia domes [14]. In our interpretation, the crestal area of the ridge formed a bulge, with a broad zone of axial structural collapse characterized by a horst and graben tectonics and subparallel crestal rifts. The axial collapse zones share similarities with the marginal basins of the orogenic arc systems on Earth. These observations indicate that folded belts and rifts have a common origin.

The Thaumasia mountain arc extends nearly $2900 \mathrm{~km}$ in length, and rises more than $4 \mathrm{~km}$ above the surrounding terrain [4]. The mountain fold belt stands up to $6 \mathrm{~km}$ above the external Icaria planum to the south, and $5 \mathrm{~km}$ above the internal Solis planum to the north [11].

\section{Thaumasia Plateau as an Orogenic Arc System}

The Thaumasian region shows a great deal of morphotectonic similarity with "orogenic arc systems" on Earth, which are known to be of a post-orogenic nature since they are superimposed upon former orogenic belts [15]. This point emphasizes the terrestrial similarity between island arcs and orogenic zones.

Typical arc systems are characterized by arcuate fronts, with their convex margins facing ocean basins or flat plains. There is an internal collapse basin on the inside of the arc that is associated with strong volcanic activity. Internal collapse basins are commonly called "marginal basins", "back-arc basins", or "inter-arc basins". Thus, the arc-back arc complex represents a distinctive element of arc systems of the western Pacific, Caribbean, and Mediterranean sea that is, arcs with marginal seas.

Essentially, the Thaumasia region consists of an "intermontane depression", which is an enclosed, interior flat area with a "central depression" that has a NE-trending orientation and a maximum diameter of about $1,500 \mathrm{~km}$ (Solis planum depression with its centre represented by Solis dorsa). The regional depression is encircled by rim highlands, formed in part by elevated arcuate mountains (Figure $1,2)$ in the eastern, southern, and western parts of the plateau edge (i.e., the "Coprates rise Minor Mountain Arc", and the "Thaumasia highlands-Claritas rise Great Mountain Arc") or by volcanic centres in the NW margin (i.e., ten coalesced small-shield volcanoes in Syria planum) [16]. The martian Great Arc is noticeably longer than the terrestrial Himalayan Arc.

The central Solis planum lowlands show common characteristics with the marginal basins (or back-arc basins) situated around the western Pacific and in the Caribbean, which are both located on the back side of uplifted mountain-thrust arcs called "accretionary prisms", and behind so-called "remnant arcs." The orogenic migration and vergence of the terrestrial arc systems are directed radially outwards, giving rise to a succession of ridges and troughs that developed progressively outwards over time.

Typical, collapsed back-arc basins are present in the Mediterranean region, too, inside major orogenic arcs, such as the Tyrrhenian basin on the concave inner side of the Calabro-Sicilian Mountain Arc, the Alboran basin inside the Betic Rif Mountain Arc, and the Aegean basin inside the Hellenic Mountain Arc. Others arc systems, such as the Pannonian (intramontane) depression enclosed inside the Carpathian Mountain Arc, are intra-continental examples. The Great Hungarian Plain is situated in the centre of the collapsed interior. Drilling in this Carpathian hinterland revealed that there was an enormous emergent landmass that experienced uplift and denudation, delivering clastic material to the adjacent flysch troughs, during the Cretaceous and Paleogene [17]. The landmass has been inverted into a large basin. The main area subsidence started in the upper Middle Miocene. 
Citation: Wezel FC, Baioni D (2018) Outline of Structural Evolution of the Thaumasian Back-Arc Trap Province of Mars, and Related Rim -Orogenic Arcs: A Speculative Hypothesis Based on Earth Geology. Int J Earth Environ Sci 3: 153. doi: https://doi.org/10.15344/2456-351X/2018/153

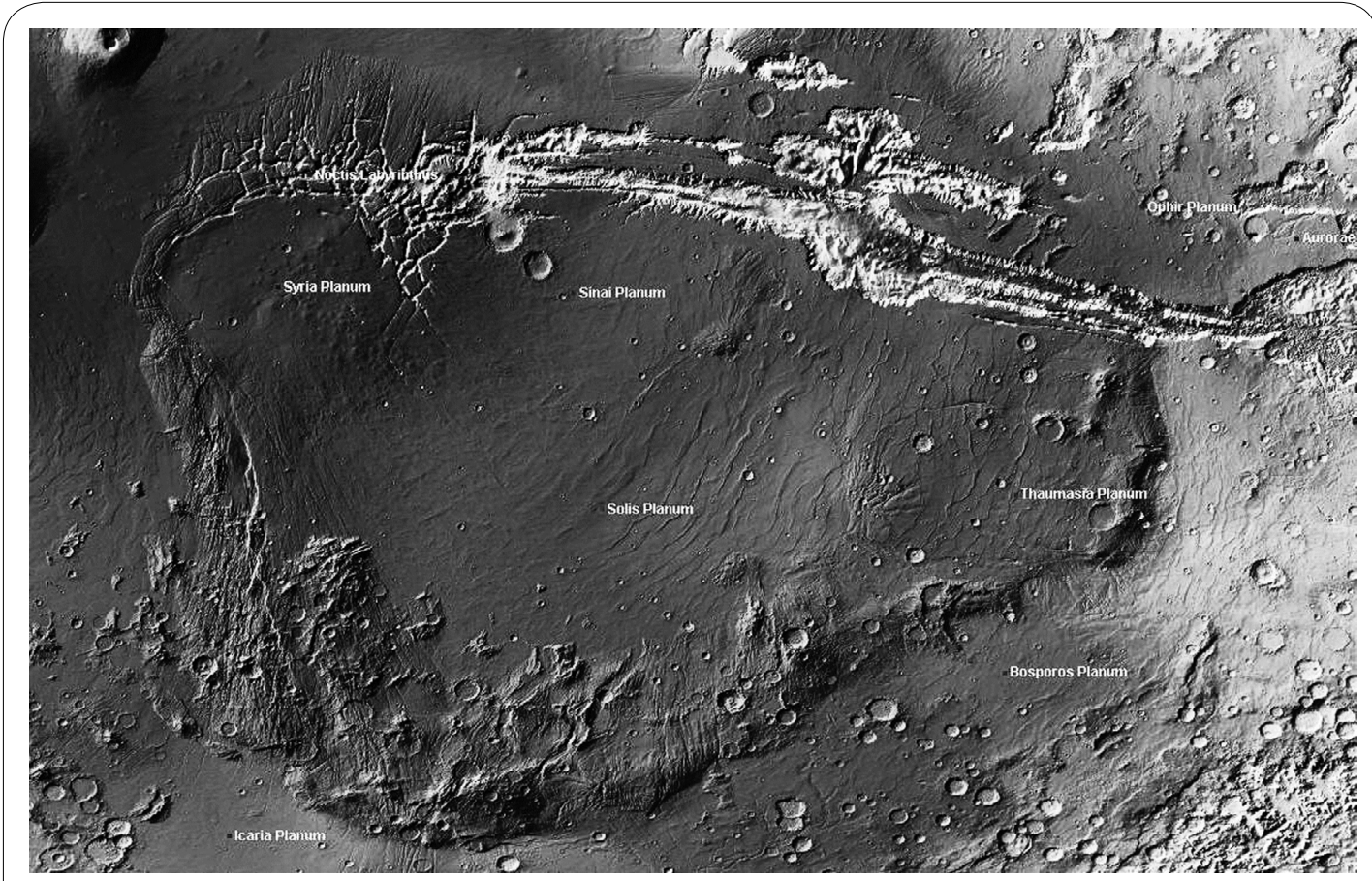

Figure 1: Topographic image map of the Thaumasian region (based on MOLA elevation data) illustrating: (a) The rim highlands (swells and arcuate mountain belts) and Valles Marineris, and (b) the back-arc lowlands (lava plains inside the arcs). Two orogenic arcs are visible: the E-vergent "Coprates Minor Arc" and the SE- to W-vergent "Thaumasia-Claritas Great Arc" (outlined by a dotted line).

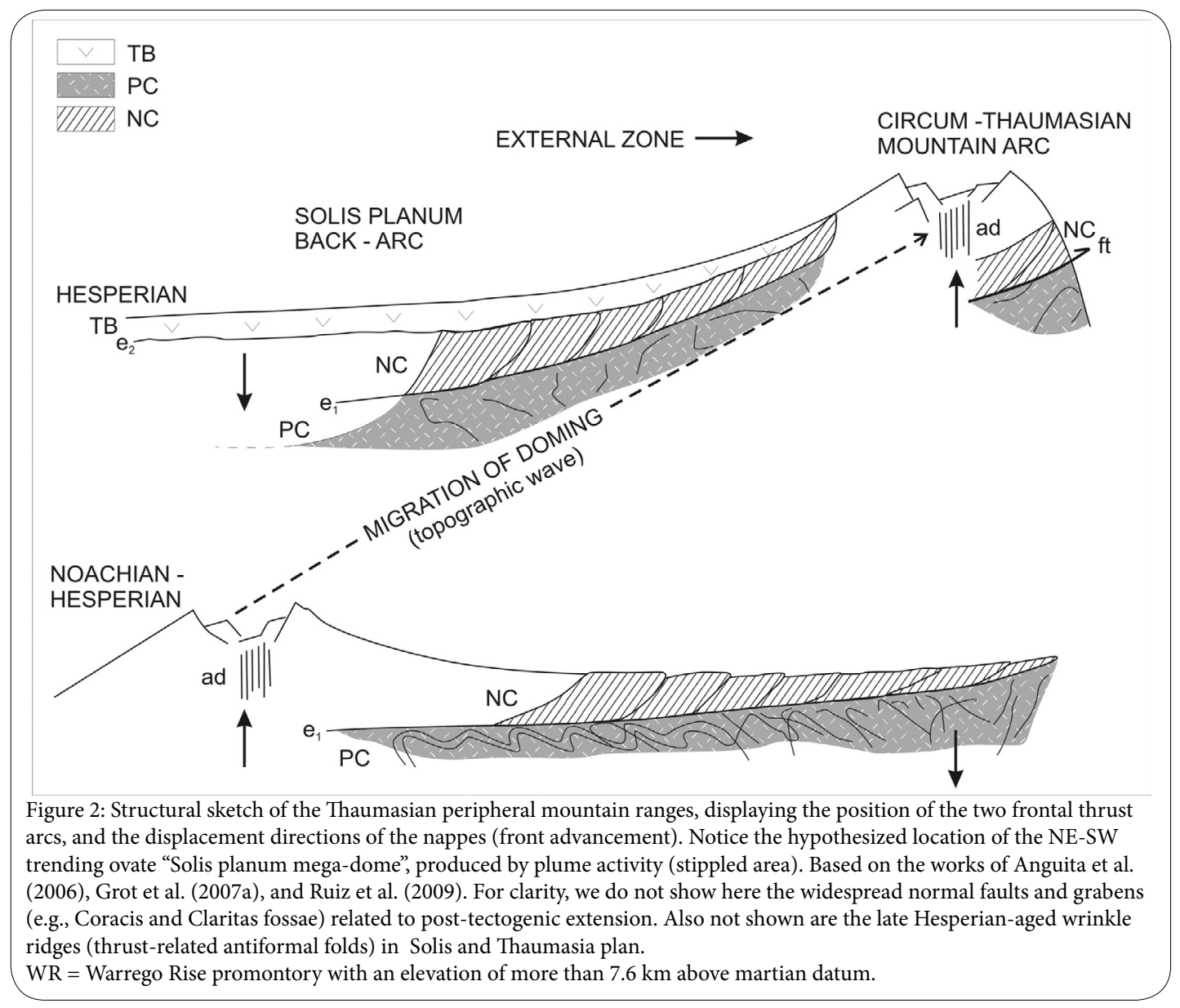


Citation: Wezel FC, Baioni D (2018) Outline of Structural Evolution of the Thaumasian Back-Arc Trap Province of Mars, and Related Rim -Orogenic Arcs: A Speculative Hypothesis Based on Earth Geology. Int J Earth Environ Sci 3: 153. doi: https://doi.org/10.15344/2456-351X/2018/153

Page 4 of 8

It should be noted that, in most cases, the back-arc basins are superimposed on the internal metamorphic core of earlier orogenic belts. Such is the case with the Pannonian depression and the marginal basins of the Mediterranean Sea.

Thus, in our interpretation, the Thaumasia plateau is a relatively foundered rigid block, partially surrounded by rapidly raised arcuate mountain ranges (thrust arcs). According to recent observations related to the late Noachian pre-trap times, the Thaumasian region was an elevated, emerged, and strongly denudated source area (hinterland) that delivered huge gypsum blocks, which accumulated as giant evaporite breccias in the adjacent subsiding marine basin [18]

\section{Multiphase Plateau Evolution}

The kinematic evolution of this region has been protracted and complicated. The building of the ovate Thaumasian flood-basalt plateau is a relatively recent episode of predominantly vertical tectonism. The Hesperian basaltic flows occurred on the back side of rising mountain arcs. The plateau was nucleated upon deep, genetically associated fold-and-thrust orogenic belts that have undergone repeated tectonic rejuvenations and inversion processes during successive orogenic periods.

We suggest that the Thaumasia region is not a high "plateau", but rather that it consists of composite foldbelts that have been affected by planation and that were covered during the Hesperian by flatlying basaltic lava flows resting on tectonically disturbed older beds, truncated, and peneplaned. Indeed, the crust under the Thaumasia highlands is approximately $80 \mathrm{~km}$ thick [19].

The Thaumasia region was occupied, at least partly, by the deformed units that now surround it (frontal ranges). Tectonic structures have experienced a history of multiple reactivations of earlier tectonized belts. Structural superimposition and overprinting occur on former tectonic structures that originated at different times, probably with different kinematic characteristics. Hence, we presume that much of the ancient deformation history of Mars has been obliterated or reduced to vestiges, allowing for only an incomplete account.

The suggested Thaumasian orogen types, here inferred to be locally and partially superimposed deformations, are tentatively distinguished as follows:

1. "Palaeo-chain" (early compressive tectonics): Ancient palaeorange of early and middle Noachian age [1], characterized by alpino type basement thrust sheets or nappes, complex tectonic structures, slivers of ophiolitic material [2] ("serpentines" identified in CRISM images) [20], and distinct magnetic signatures. The orogenic realm is consideredto be larger than the present Thaumasia plateau [5].

2. "Neo-chain" (thin-skinned tectonics)- The most superficial, relatively young neotectonic "cover range" consists of sedimentary décollement nappes (supracrustal wedge). Later tectonism overprints earlier tectonic units and tectonization; there is possible block-faulting-induced gravity sliding of the sedimentary cover, and tectonic divergence away from the uplift (divergent thrusting). The central part of the regional uplift collapsed and was compensated for by a peripheral uplift of the mountain arcs.

\section{Stages in Deformation of the Thaumasia Region}

In our interpretation, the Thaumasia region has been affected and impressed by repeated pulses of thrust tectonics, vertical tectonics, and more recent widespread mafic volcanism. These processes denote successive episodes of tectonothermal activity (high heat flow and mafic fluids), and associated tectonic rejuvenations of the ancient deformed structures during successive orogenic phases. Hence, the region has suffered either a polyphased or a multicyclic structural evolution, starting from its origin as an ancient Noachian orogenic zone deep in the crust, continuing with the later formation of the Hesperian lava plateau.

The following phases and climaxes of orogeny (both tectonic and morphologic events) can be recognized in the Thaumasian tectonic province, with distinctive styles of deformation:

Phase 1: (Alpinotype intense compression with genesis of tightly deformed orogenic belt).

Ancient pre-Tharsis eo-orogenic compressional phases (early to middle Noachian), which may also affect neighboring zones beyond the Thaumasia plateau (i.e., Daedalia planum, Aonia terra and Nereidum montes, according to [5]). Relics of alpinotype ancient structures have been found in the Coprates rise, Thaumasia highlands, and Claritas rise mountain ranges, showing E-verging, S-verging, and $\mathrm{W}$-verging frontal thrusting, respectively. Much of the evidence for the earlier events has been lost, because of the overprinting character of subsequent compressional structures, and the fragmentation of the chain caused by the later development of the extensional plateau.

Our ancient alpinotype orogen corresponds well with the "Thaumasia-Aonia Orogen" [5], except for its younger age attribution (Noachian-early Hesperian times). The Thaumasia highlands belt has also been compared to orogenic belts on Earth (e.g., Alpine Cantabrian Belt chain, west of the Pyrenees). According to [5], the orogen is characterized by big folds of the basement directed E-W, interpreted as being caused by powerful, large-scale lithospheric deformation by plate tectonics.

The alpinotype structural features [2] include magnetic signatures (remnant crustal magnetization), complex tectonic structures (thrust and fold nappes, basement thrust sheets), crystalline basement (igneous and/or metamorphic rocks), and the presence of possible slivers of ophiolitic material (e.g., possible serpentinized peridotites, maybe relics of an ocean floor), commonly found in the core zones of terrestrial orogens.

Morphologic characteristics include cuestas formed by the erosion of thrusts, hogbacks, and valley networks, which are similar to those present in mountain ranges of Earth [21].

The Thaumasia highlands arc extends nearly $2900 \mathrm{~km}$ in length, and rises more than $4 \mathrm{~km}$ above the surrounding terrain [4]. The mountain belt stands up to $6 \mathrm{~km}$ above external Icaria planum to the south, and $5 \mathrm{~km}$ above internal Solis Planum to the north [22].

Phase 2: (Major regional uplift of the chain in the internal domain, active graben-like troughs at the bulge crest, deep erosion and dissection of the mountainous relief with final near-peneplanation, and huge influx of thick breccia volumes in the external zones). 
Citation: Wezel FC, Baioni D (2018) Outline of Structural Evolution of the Thaumasian Back-Arc Trap Province of Mars, and Related Rim -Orogenic Arcs: A Speculative Hypothesis Based on Earth Geology. Int J Earth Environ Sci 3: 153. doi: https://doi.org/10.15344/2456-351X/2018/153

Page 5 of 8

After the cessation of compressional deformation, a major late Noachian phase occurred, with broad doming and tilting of orogenic highlands attaining mountainous relief, followed by a high stripping rate, with development of planation erosion surfaces and redeposition of very large volumes of molasses-like giant breccias, eroded from the hinterland internal uplifts. The uparching of the crust caused crestal tension and graben formation by structural collapse (rift taphrogenic stage).

The rapid uplift was probably generated by heat-driven magmatic fluid fluxes ascending from the interior of the martian mantle. The high-standing plateau formation occurred by voluminous mafic intrusions into the axial region (mafic dyke swarms). We suggest that magmatic fluids may have risen from the mantle as nearly vertical dykes and laccolith-like bodies, and subsequently spread as sills of different lateral extents. We postulate that plume activity consists mainly of ascending deep mantle fluids, possibly with a pulsatory character, giving rise to pulsations in volcanic activity. The rapid elevation could represent a morphotectonic, orogenic phase of supracrustal arching and fracturing, subsequent to the compressional shortening and crustal thickening of the older alpinotype "Palaeochain".

plateau on Earth, the Tibetan (Qinghai-Xizang) plateau (area of $\sim 5.2$ million $\mathrm{km}^{2}$ and average elevation of $\sim 5 \mathrm{~km}$ ). According to previous studies, during the present morphogenic phase, the whole Tibetan block was strongly uplifted by $3-4,000 \mathrm{~m}$ in Pleistocene times [23]. The strong, vertical elevation is counteracted by a deep erosion, producing an enormous volume of molassic detritus and erosion planation surfaces, giving the Tibetan plateau its modern appearance of an uplifted erosional pediplain. As with the Tibetan plateau, the Thaumasia plateau consists of a median plateau bounded by higher outward verging mountain ranges.

Phase 3: "Neo-chain" or "chaine de couverture" of early Hesperian age, characterised by superficial décollement nappes, changes of vergence in thrusting and formation of peripheral thrust arcs).

The thin-skinned (suprabasement), deformed "Neo-chain" ("chaine de couverture"), which was superimposed on older tectonic deformations of the "Palaeo-chain", consists of décollement thrust sheets detached from a crystalline basement. The changes in thrusting vergence are manifested by two major frontal ranges, the E-vergent "Coprates rise Minor Arc" and the SE- to W-vergent "Thaumasia highlands-Claritas rise Great Arc". It is possible that the different thrusting directions indicate diachronous deformations that can be related to different kinematics. We suggest later the possibility of the presence of two independently evolving mantle domes.

In our opinion, the two main explanations of décollement nappe emplacement consist of the following mechanisms:

\section{Gravitational spreading:}

The Thaumasian peripheral mountain belts have been explained as having resulted from gravitational spreading on the flank of Syria planum elevated topography (plume-generated swell) $[5,24]$. We note that gravity spreading [25] or gravitational collapse [26,27] requires the tenet of a simultaneous coexistence of states of compression (thrusting), in the lower-elevation external border of the chain, and extension (block faulting), in the high-elevation internal domains. Due to the practical impossibility of proving the existence of an extensive normal faulting in the inner zones of the orogenic belt that is commensurate, synchronous, and associated with external shortening, we failed to find indications of the applicability of this model on Mars.

\section{Wave-like, foredeep outward migration:}

We suggest that the thin-skinned tectonism of martian phase 3 was likely caused by fluid-impelled vertical displacements of the crust, as occurs on Earth in major tectonic features such as the orogenic belts and arc systems.

Some geologists $[28,29]$ have explained the origin of the Apennine chain, where the sedimentary cover is detached from its basement, in terms of an outward-moving "orogenic wave" (a wave of folding and tectonic deformation) originating in the internal zones and moving across, progressively affecting more external zones of the foldbelt [30]. According to one of the interpretation proposed for the Tyrrhenian basin [31] , the upper sector of plastic asthenosphere - accumulated on the top of mantle dome by uprising deep mantle aqueous fluids and very rich in incompatible elements - will slide laterally to the mantle dome. Lateral displacement of hot currents of plastic mantle flows, within the lower crust, should cause tectonic deformation of the overlying, brittle, crustal sector, which is involved in this sliding down the flanks of the uplift. Furthermore, the transfer of fluid content induces collapse of the elevated bulge, with consequent basin formation.

On Earth, there is widespread presence of aqueous fluids and/or a partial melt throughout the Tibetan plateau crust, at depths of 15 to $20 \mathrm{~km}$ and 30 to $40 \mathrm{~km}$ with fluid zones perhaps representing weaker areas that could accommodate deformation and lower crustal flow.

In the case of the Thaumasian uparching we suppose that the rise of thermal plumes may account for the "orogenic wave" as well as for the gravitational gliding of the stratigraphic cover. An outward shifting of the long-wavelength regional doming during the late Noachian-early Hesperian also seems possible.

The wave hypothesis can also be applied to arc systems on Earth $[32,33,34]$. The emplacement of the thrust sheets occurred by topographic, wave-like migration of transient uplift and subsidence axes, developed progressively in time, and interpreted as related to shifting "undulations" of the underlying plastic mantle material [30].

In the Timor trough foredeep, which is part of the Indonesian arc system, the facies sequence shows a topographic wave that has migrated $80 \mathrm{~km}$ southwards over the past $3 \mathrm{~m} . \mathrm{y}$. [35]. The migration consists of the advance, in a wave form of 6-km amplitude and 100-km half-wavelength, of vertical motions of the concomitant subsidence of the Timor trough and uplift of the island of Timor. Thus, a succession of ridges and troughs developed outwards in time from the inside of the arc by such "touche-de-piano" vertical tectonics.

It is our view that the migrating "wave" is related to outward lateral spreading via magmatic sill-like conduits of hot fluid to semifluid mantle materials (i.e., heat and mafic fluid flows) located beneath the domed internal zones. The ability of the mobile hot material to intrude horizontally for long distances generates plastic magmatic fluid flows, triggering elevation and collapse of surface segments of the overlying more rigid crust, and therefore the external-shifting "orogenic wave". 
Citation: Wezel FC, Baioni D (2018) Outline of Structural Evolution of the Thaumasian Back-Arc Trap Province of Mars, and Related Rim -Orogenic Arcs: A Speculative Hypothesis Based on Earth Geology. Int J Earth Environ Sci 3: 153. doi: https://doi.org/10.15344/2456-351X/2018/153

Page 6 of 8

Over time, episodic inversion processes can convert basinal areas into structural highs, and vice versa, giving rise to the pulse-like character of crustal deformation (Figure 3).

Phase 4: (Hesperian period. Tectonic inversion process converting the structural high into a basin. Post-orogenic regional collapse and crustal foundering of the Thaumasian back-arc province, with compensatory balance by pronounced vertical rise of the peripheral rim swells, such as mountain arcs, and extrusion of trap basalts).

The phases of mafic activity, with penetration at the surface of mantle magmatic fluids, coincide approximately with the phases of crustal subsidence. We interpret the internal collapse to be a consequence of the elevation of the peripheral rim-highlands (e.g., arcuate mountain chains and swells). We envisage that peripheral mountain arcs arose first, delivering clastic sediments into the subsiding back-arc area, and then a capping basalt lava pile was emplaced inside the back-arc collapsing lowland (Figure 3). A widespread effusion of extensive flood-basalt flows appears behind (i.e., on the concave side) the uplifting circum-Thaumasian highland arcs; these basalt flows flood, in the form of "lava seas", the huge ovate Thaumasian flat territory, which has been depressed by regional crustal subsidence. Basalt lava flows inundate the ovate depression inside the arcuate orogenic belts It is possible that the penetration by hot magmatic fluids from the mantle occurred episodically in coincidence with accelerated phases of regional crustal subsidence.

We note a similarity of the huge Thaumasian plateau basalts with the large igneous provinces (LIPs) on Earth, which are huge, ovate, continental flood-basalt emplacements, such as the Siberian Traps, Deccan Traps, Karroo flood-basalts, and Ethiopian Plateau basalts; they represent the largest outpourings of mafic magma on the terrestrial surface. It seems probable that the Thaumasian flood basalts were emplaced by rapidly-shifting eruptive centres, as occurred in the Siberian and Deccan traps.

\section{Position of Thaumasian Topographic Mega-dome}

From our interpretation emerges a long structural evolution leading to the present-day configuration of the Thaumasian plateau region. The history, consisting of a set of tectonic episodes, precludes any explanation that is based on the modern structure, which is only the final result of all of the changes that have occurred. Thus, we consider it unlikely that the "mega-slide" model is founded on the present-day south-east ernward regional slope, rather than the estimate of a formerly pre-deformation topographic slope, obtained from restoration of Thaumasian palaeogeographic sections.

In our opinion, the topographic relief has changed repeatedly and has existed in forms that were completely different from the present situation. We suggest that a broad topographic bulge was situated on the present-day site of Solis planum central lowlands. This geodynamic process was probably a consequence of diapiric upwelling of heat flow and deep mantle magmatic fluids (or thermal mantle plume) beneath the central Thaumasian depression. A large scale inversion process caused the transformation of the temporary structural high into a depression, during Hesperian times.

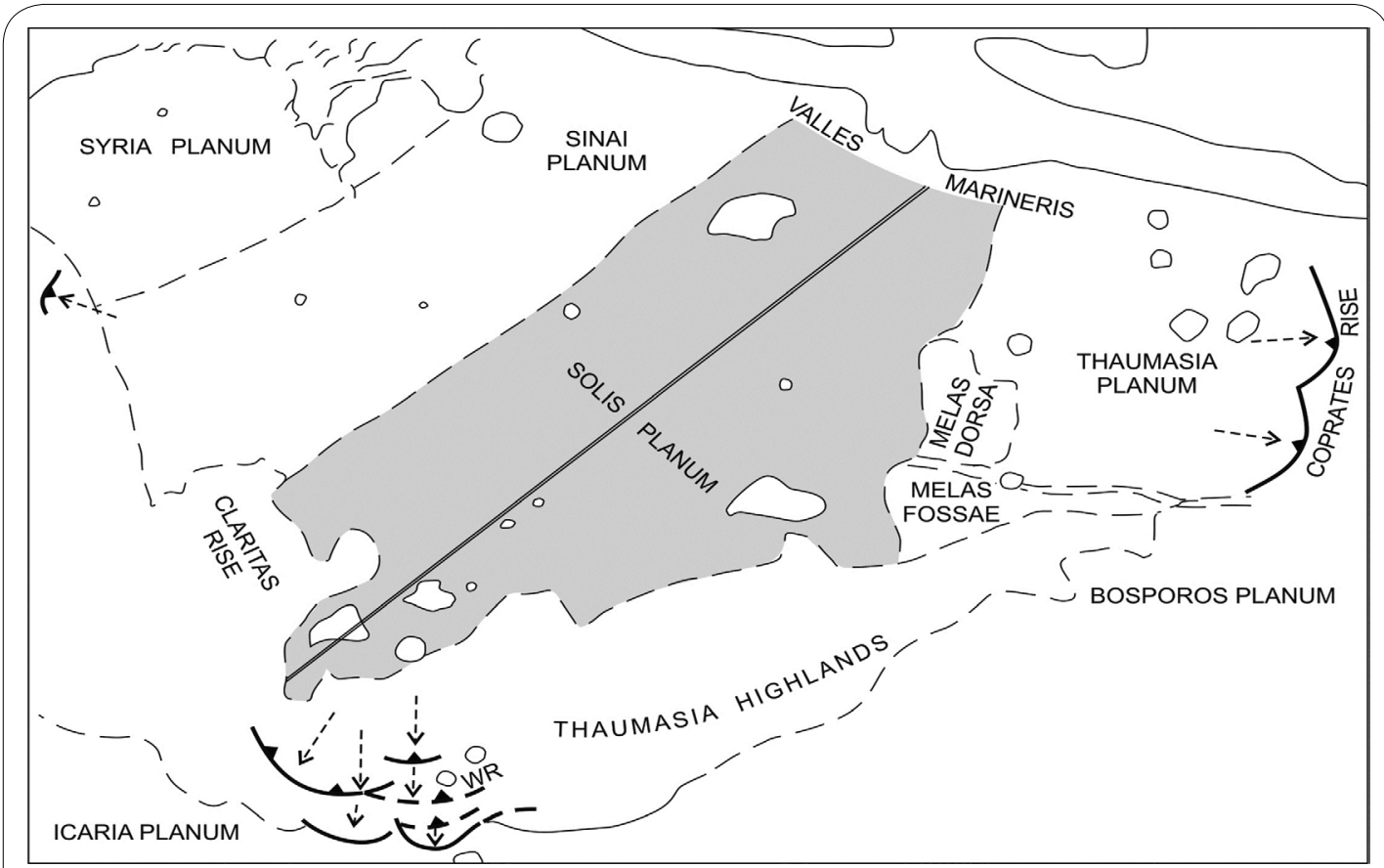

Figure 3: Diagrammatic, interpretive cross-sections through the Thaumasian region, showing its hypothetical topographic evolution through time. The interpretation suggested here is the occurrence of differential vertical displacements in time and space of fractured crust, which may reflect compensation at depth by horizontal movement of subcrustal magmatic fluid. Note the reversal of the direction of vertical movements during the "topographic wave" outward migration, and the cracks on the crest of the doming.

Labelled features are: $\mathrm{PC}=$ Basement nappes of the Palaeo-chain; NC = Sedimentary nappes of the Neo-chain, included thick gypsum mega- breccias on the top (not indicated here, but for the description of such resedimented clastic evaporites); $\mathrm{TB}=$ Trap basalts; $\mathrm{e}_{1}, \mathrm{e}_{2}=$ erosional surfaces; $\mathrm{ad}=$ axial dykes; $\mathrm{ft}=$ frontal thrusts . 
Citation: Wezel FC, Baioni D (2018) Outline of Structural Evolution of the Thaumasian Back-Arc Trap Province of Mars, and Related Rim -Orogenic Arcs: A Speculative Hypothesis Based on Earth Geology. Int J Earth Environ Sci 3: 153. doi: https://doi.org/10.15344/2456-351X/2018/153

Page 7 of 8

Theere May be two distinct mantle domes?

The possibility of there being at least two distinct, independently evolving mantle domes (thermal plumes) with different migration directions is proposed here on the basis of the orientation and configuration of the two peripheral thrust arcs (Figure 2). The different directions of the migrating diapirs can account for the differing tectonic evolution between the eastward-facing Coprates rise Minor Arc and the southwestward-facing Thaumasia highlands-Claritas rise Great Arc. The arcuate structures of the former are thought to have been generated by an eastward-directed thermal plume (perhaps, Thaumasia Minor plume), while the latter features may have been generated by a south-westward-directed dome through time.

\section{Lateral migration of subcrustal thermal plumes}

The great elevation of the Solis planum regional doming caused the formation in the dome-flank of slopes steep enough for a lateral sliding- down of a subcrustal flowage of hot mobile magmatic fluids, producing thin-skinned tectonic deformation. It is assumed that the mantle material is distributed nearly horizontally by intrusion close to the lower boundary of the crust.

Mafic sills can intrude deep fractures that extend for hundreds of kilometres beneath Pacific back-arc basins [34]. Hence, we suppose that magmatic fluids on Mars rose to shallow levels along nearly vertical dyke like channels, and spread laterally as sills. The flowage of plastic mass of high heat flow and mafic fluids caused the formation of an "orogenic wave", and thus produced the tectonic deformation of the overlying crust. We therefore suggest that the décollement nappes of phase 3 were generated by the strong morphogenic uplift of the mantle-controlled "Solis planum High" and not by a subsequent "extensional" collapse of the ridge (phase 4), which is regarded as a major tectonic model on Earth.

We interpret the inter-balancing between crustal uplift of the external mountain arcs and the sinking of the internal plateau as evidence of compensation at depth, caused by lateral heat-driven mafic fluid displacement. The lateral subcrustal movement acts to raise or lower segments of the overlying brittle crust. The upheaval of the peripheral mountains and swells, accompanied by the relative subsidence of the interior lowland, are thus hypothesized to result from this deep lateral flow of hot fluids.

\section{Synthesis of The Main Phases of Tectonic Evolution}

The Thaumasian plateau region is the result of a complex and multiphase history, presumably reflected in a succession of two possible, partly-superposed orogenic belts (Figure 3). The recent tectonic deformations have reshaped and disrupted the previous nappe structures.

1. The Thaumasia plateau region is superimposed on an area that was already deformed and previously occupied by an ancient orogenic belt (our "Palaeo-chain"), consisting of basement nappes, intensely tectonized by large-scale alpinotype crustal compression, mostly during early and middle Noachian.

2. Abnormally important endogenic heat and magmatic fluid contributions rise diapirically from the mantle in the form of thermal plumes, with regional updoming accompanied by crestal collapse of the arched uplifts. The location of the broad, regional topographic bulge, uplifted during the late Noachian, is supposed to correspond with the present Solis planum depression (Figure 2). A taphrogenic phase of block faulting with graben-like troughs was then generated. The block-faulted and tilted elevated relief was deeply truncated by an intense erosion, and nearly peneplained. Extensive planation probably occurred in phases (plateau formation). Great volumes of clastic detritus which have been removed by erosion were turbidite-transported and heavily redeposited in the foredeep basins as thick wedges of gigantic gypsum breccias [18].

3. A further deformation phase of thin-skinned tectonism, consisting of sedimentary décollement nappes (or thrust sheets) with outward thrusting forming the two peripheral thrust arcs, may have been generated in late Noachian-early Hesperian by lateral spreading of hot mafic fluid fluxes away from the main plume centre, along sill-like channels of differing lateral extents within infracrustal levels (weak zones), causing tectonic deformation of the overlying brittle supracrustal levels (in the manner of a shifting "orogenic wave" progressively affecting more external zones). The folding and imbrication of this new phase formed the "Neo-chain" which overprinted the previous alpinotype structural patterns. The two distinct orogenic arcs of the Coprates and Thaumasia-Claritas belts are external zones affected by major overthrusting, possibly not contemporaneously. We assume that the thrust arcs were generated by differential displacements (eastward-and southwestward-facing), probably separated by transverse tectonic lineaments (Figure 2). We propose here that there may have been two distinct independently evolving domes (thermal plumes), with different directions of "waves" or gravity gliding migration, on the basis of the orientation and configuration of the two peripheral thrust arcs. No regional lithospheric motion appears to have been necessary.

4. A profound change in tectonic evolution is assumed to have occurred during the Hesperian period. It consists essentially of post-orogenic regional subsidence and foundering of the back-arc plateau. The early stages of regional subsidence were accompanied by a vast outpouring of great masses of trap basalt ("crustal basification"). Concomitant with the inferred downwarping of the interior plateau, the peripheral arcuate orogens and swells have undergone a counterbalanced uplift (Figure 3) that gave rise to the present-day, elevated arcuate mountain ranges bordering the Thaumasian plateau, and to crestal graben troughs. Accordingly, we appoint the Thaumasian final extensional tectonics as probably occurring in late Hesperian $[21,36]$ and the genesis of the Valles Marineris as starting during Hesperian times.

The magmatic-driven uplifts of the arcuate rim-highlands (mountain ranges and swells) were accompanied by crestal tension fracturing with formation of subsiding graben-like troughs. Concerning the question addressed by [37], it is here proposed that "fluid-flow tectonics", with subcrustal lateral displacement of mantlederived hot mafic fluids, is probably the basic process that accounts for the big collapse of the crust directly over the presumably thick "fluid wedge", causing the great depth of the large tectonic troughs of Valles Marineris.

The subsiding Thaumasian flat region (i.e., Solis planum) was flooded by trap basalt flows, forming a vast "trap sea" on the backside of the rising arcuate ranges and swells, which are presently elevated 
Citation: Wezel FC, Baioni D (2018) Outline of Structural Evolution of the Thaumasian Back-Arc Trap Province of Mars, and Related Rim -Orogenic Arcs: A Speculative Hypothesis Based on Earth Geology. Int J Earth Environ Sci 3: 153. doi: https://doi.org/10.15344/2456-351X/2018/153

Page 8 of 8

above the Solis planum by as much as $5 \mathrm{~km}$ [22]. Trap basalts covered an already planated orogenic landscape during the extensive erosion of phase 2 (Figure 3 ).

\section{Concluding Remarks}

The hypothetical kinematic scheme given here represents only a rough and brief approach to the complex and varied evolution of the Thaumasian plateau and its peripheral orogens. The tectonic complexity derives from the fact that the region was subjected to a long deformation history and the superimposition of overprinting structures, with consequent obliteration or obscuring of earlier deformation structures on Mars by subsequent tectonisation. On the other hand, recent patterns are genetically derived and predetermined by earlier dislocations in the crust, as the system is a reflection of what lies underneath.

The rooting of a lava plateau on orogenic belts is indicative of repeated renewal of tectonism and related magmatism at the same sites. The genetic association with ancient orogenic zones may reflect the existence of martian tectono magmatic pulses, related to bursts of high heat flow, together with fluids, presumably rising from the mantle through long-lived sub-vertical dyke-like channels.

It is hoped that the scheme proposed here will facilitate the choice among the different hypotheses, considering the long ancestry of their structural development. This approach implies the rejection of simplistic interpretations that are based solely on later events in Thaumasian deformation history, omitting long sections of the earlier past. It is also our anticipation that the present scheme may stimulate further studies of the processes conceptualized and described herein.

\section{Competing Interests}

The authors declare that no competing interests exist.

\section{References}

1. Dohm JM, Ferris JC, Baker VR, Anderson RC, Hare TM, et al. (2001) Ancient drainage basin of the Tharsis region, Mars: potential source for outflow channel systems and putative oceans or paleolakes. J Geophys Res 106: 943-958.

2. Dohm JM, Anderson RC, Williams JP, Ruiz J, McGuire PC, et al. (2009) Claritas rise, Mars: Pre-Tharsis magmatism?. Journal of Volcanology and Geothermal Research 185: 139-156.

3. Schultz RA, Tanaka KL (1994) Lithospheric -scale buckling and thrus structures on Mars: The Coprates rise and south Tharsis ridge belt. $J$ Geophys Res 99: 8371-8385.

4. Dohm JM, Tanaka KL (1999) Geology of the Thaumasia region, Mars: Plateau development, valley origins, and magmatic evolution. Planet. Space Sci 47: 411-431.

5. Anguita F, Fernandez C, Cordero G, Carrasquilla S, Anguita J, et al. (2006) Evidences for a Noachian-Hesperian orogeny in Mars. Icarus 185: 331 357.

6. Borracini F, Di Achille G, Ori GG, Wezel FC (2007) Tectonic evolution of the eastern margin of the Thaumasia Plateau (Mars) as inferred from detailed structural mapping and analysis. J Geophys Res 112: E05005.

7. Montgomery DR, Sanjoy MS, Jackson MPA, Schreiber BC, Gillespie AR, et al. (2009) Continental-scale salt tectonics on Mars and the origin of Valles Marineris and associated outflow channels. GSA Bulletin 121: 117-133.

8. Bally AW (1981) Thoughts on the tectonics of folded belts. In: Thrust and Nappe tectonics. Geol Soc London 9: 13-32.

9. Nahm AL, Schultz RA (2010) Evaluation of the orogenic belt hypothesis for the formation of the Thaumasia Highlands, Mars. J Geophys Res 115: E04008.
10. Andrews- Hanna JC (2009) A mega-landslide on Mars. Nat Geosci 2: 248249.

11. Grott M, Hauber E, Werner SC, Krongberg P, Nekum G, et al. (2007) Mechanical modeling of thrust faults in the Thaumasia region, Mars, and implications for the Noachian heat flux. Icarus: 186: 517-526.

12. Mège $D$, Masson $P(1996)$ A plume tectonics model for the Tharsis province, Mars. Planet Space Sci 44: 1499-1546.

13. Schultz RA, Lin J (2001) Three-dimensional normal faulting models of the Valles Marineris, Mars, and geodynamic applications. J Geophys Res 106 16549-16566.

14. Dunkelman TJ, Karson JA, Rosendahl BR (1988) Structural style of the Turkana rift, Kenya. Geology 16: 258-261.

15. Wezel FC (1986) The Pacific island arcs: produced by post-orogenic vertical tectonics? In: Wezel FC (Ed.) The Origin of Arcs. Elsevier. Developments in Geotectonics 21: 529-567.

16. Xiao L, Smith M, Huang J, He Q, Petford N et al (2009) Volcanic features on the Syria-Thaumasia block, Mars: Implications for ancient martian volcanology. 40th Lunar Planet Sci Conf.

17. Contescu LR (1974) Geologic history and paleogeography of Eastern Carpathians: Example of Alpine geosynclinal evolution. Bull Am Assoc Petrol Geol 58: 2436-2475.

18. Wezel FC, Baioni D (2010) Evidence for subaqueously resedimented sulphate evaporites on Mars. Planet Space Sci 58: 1500-1505.

19. Zuber MT, Solomon SC, Phillips RJ, Smith DE, Tyler GL, et al. (2000) Internal structure and early thermal evolution of Mars from Mars Global Surveyor topography and gravity. Science 287: 1788-1793.

20. Ehlmann BL, Mustard JF, Murchie SL (2009) Detection of serpentinites on Mars by MRO-CRISM and possible relationship with olivine and magnesium carbonate in Nili Fossae. 40th Lunar Planet Sci Conf.

21. Dohm JM, Williams JP, Anderson RC, Ruiz J, McGuire PC, et al. (2009) New evidence for a magmatic influence on the origin of Valles Marineris, Mars. Journal of Volcanology and Geothermal Research 185: 12-27.

22. Grott M, Hauber E, Kronberg $P$ (2007) Martian rifting in the absence of plate tectonics? Seventh Intern Conf Mars.

23. Gansser A (1991) Facts and theories on the Himalayas. Eclogae geol Helv 84: 33-59.

24. Mège D, Ernst RF (2001) Contractional effects of mantle plumes on Earth Mars, and Venus. Geol Soc Am 352: 103-140.

25. Elliott D (1976) The motion of thrust sheets. J Geophys Res 81: 949-963.

26. Royden LH, Burchfiel BC (1987) Thin-skinned N-S extension within the convergent Himalayan region: gravitational collapse of a Miocene topographic front. Geol Soc Spec Publ 28: 611-619.

27. Dewey JF (1988) Extensional collapse of orogens. Tectonics 7: 1123-1139.

28. Merla G (1951) Geologia dell'Appennino settentrionale. Boll Soc Geol Ital 70: $92-382$

29. Caire A (1973) The Calabro-Sicilian Arc. Gravity and Tectonics. John Wiley.

30. Wezel FC (1985) Structural features and basin tectonics of the Tyrrhenian Sea. Geological Evolution of the Mediterranean Basin. Springer Verlag 153-194

31. Locardi E (1985) Neogene and Quaternary Mediterranean volcanism: The Tyrrhenian example. Geological Evolution of the Mediterranean Basin. Springer Verlag New York 273-291.

32. Krebs W (1975) Formation of southwest Pacific island arc-trench and mountain systems: plate or global-vertical tectonics? Bull Am Ass Petrol Geol 59: 1639-1666.

33. Sharaskin AY, Bogdanov NA, Zakariadze GS (1981) Geochemestry and timing of the marginal basin and arc magmatismin the Philippine Sea. Phil Trans R Soc Lond A 300: 287-297.

34. Sychev PM, Sharaskin AY (1984) Heat flow and magmatism in the NW Pacific back-arc basins. Blackwell Scientific Publ 173-181.

35. Veevers JJ, Falvey DA, Robins S (1978) Timor trough and Australia: Facies show topographic wave migrated $80 \mathrm{~km}$ during the past $3 \mathrm{~m} . \mathrm{y}$. Tectonophysics 45: 217-227.

36. Hauber E, Kronberg P (2005) The large Thaumasia graben on Mars: Is it a rift? J Geophys Res 110: E07003.

37. Dohm J, Anderson RC, Baker VR, Tanaka KL, Hare TM, et al. (2008) New Evidence for a Magmatic Influence on the Origin of Valles Marineris. 39th Lunar Planet Sci Conf. 